\title{
Formulation and evaluation of fast dissolving tablet of albendazole
}

\author{
*Devendra Revanand Rane, Hemant Narhar Gulve, Vikas Vasant Patil, Vinod Madhaorao Thakare, Vijay Raghunath Patil \\ Department of Quality Assurance, Tapi Vally Education Society's Hon'ble Loksevak Madhukarrao Chaudhari College of Pharmacy, \\ Faizpur, Jalgaon, Maharashtra, India
}

\begin{abstract}
Albendazole is broad spectrum anthelmintic use against many helminths. It is used for treatment of Threadworm, Hookworm, and Tapeworm. It has low bioavailability due to its first pass metabolism. In the present work, fast dissolving tablet of Albendazole was design with a view to and provide a quick onset of action. The main objective of the study was to formulate fast dissolving tablets of Albendazole to achieve a better dissolution rate and further improving the bioavailability of the drug. Fast dissolving tablets prepared by direct compression and using super disintegrants in different concentration and evaluated for the pre-compression parameters. The prepared tablets were evaluated for post compressional evaluation. Among all, the formulation F3 containing 5\%w/w superdisintegrant Crospovidone and $20 \% \mathrm{w} / \mathrm{w}$ Microcrystalline Cellulose was considered to be best formulation, which release up to $99.097 \%$ in $40 \mathrm{~min}$.
\end{abstract}

Key Words: Albendazole, superdisintegrants, in vitro disintegration time, in vitro dissolution test.

\section{INTRODUCTION}

Recent advance in novel drug delivery system aims to enhance the safety and efficacy of the drug molecule by formulating a dosage form being for the administration (Kuchekar et al., 2003). Difficulty in swallowing is experienced by patient such as pediatric, geriatric, bedridden, disabled and mentally ill (Seager et al., 1998). Fast dissolving tablets are solid dosage form containing medical substances which disintegrate rapidly, usually within few seconds when placed upon tongue requiring no additional water to facilate swallowing (Shu et al., 2002; Bradoo et al., 2001). Albendazole (ABZ), methyl [5-(propylthio)-1-H-benzimidazol-2yl] carbamate, is a benzimidazol derivative with a broad spectrum of activity against human and animal helminth parasites (Cook et al., 1990). ABZ is effective in the treatment of echinococcosis, hydrated cysts and neurocysticercosis (Wen et al., 1993).

Direct compression is one of the techniques requires

\footnotetext{
*Corresponding Author:

Devendra Rane, M.Pharm Student

Tapi Vally Education Society's Hon'ble Loksevak

Madhukarrao Chaudhari College of Pharmacy

Faizpur, Jalgaon, Maharashtra, India

E-mail: drane18@yahoo.com

Contact No.: +9403831824
}

the incorporation of a superdisintegrants into the formulation the use or highly. The basic approach used in development of FDT was the use of superdisintegrants like cross linked Croscarmellose Sodium, Polyvinyl Pyrrolidone K30, Microcrystalline Cellulose, Crospovidone etc. which provide instantaneous disintegration of tablet after placed on tongue, thereby releasing the drug in saliva.

\section{MATERIAL AND METHODS}

Albendazole was obtained as a gift sample from Brasica Pvt. Ltd. Boisar (India). Crospovidone, Microcrystalline cellulose and Croscarmellose sodium were gift sample from Curex Pharma, Jalgaon. Polyvinyl Pyrrolidone K30 was obtained as gift sample from Emcure Pharma, Pune and Mannitol, Aspartame were gift samples from Merck Ltd, Mumbai, India. All chemicals and reagents used were of analytical grade.

\section{Preparation of fast dissolving tablets}

Fast dissolving tablets of Albendazole were prepared using direct compression method incorporating superdisintegrants Microcrystalline cellulose (MCC), Crospovidone (CP), Croscarmellose Sodium (CCS), Polyvinyl Pyrrolidone K30 
Table 1: Formulation of albendazole fast dissolving tablets.

\begin{tabular}{|c|c|c|c|c|c|c|c|c|c|c|}
\hline \multirow{2}{*}{ Ingredients } & \multicolumn{10}{|c|}{ Formulations } \\
\hline & F 1 & F 2 & F 3 & F 4 & F 5 & F 6 & F 7 & F 8 & F 9 & F 10 \\
\hline Albendazole (mg) & 200 & 200 & 200 & 200 & 200 & 200 & 200 & 200 & 200 & 200 \\
\hline Microcrystalline cellulose* & - & - & 20 & 20 & - & 20 & 15 & 15 & - & 15 \\
\hline Crospovidone $^{*}$ & 5 & - & 5 & - & 5 & 5 & 5 & - & 5 & 5 \\
\hline Croscarmellose sodium* & - & 5 & - & 5 & 5 & 5 & - & 4 & 4 & 4 \\
\hline Polyvinyl Pyrrolidone K30* & 3 & 3 & 3 & 3 & 3 & 3 & 3 & 3 & 3 & 3 \\
\hline Aspartame ${ }^{*}$ & 2 & 2 & 2 & 2 & 2 & 2 & 2 & 2 & 2 & 2 \\
\hline Magnesium Stearate & 1 & 1 & 1 & 1 & 1 & 1 & 1 & 1 & 1 & 1 \\
\hline Mannitol q.s.(mg) & 500 & 500 & 500 & 500 & 500 & 500 & 500 & 500 & 500 & 500 \\
\hline
\end{tabular}

${ }^{*}$ Amounts of ingredients are in percentage (\%)

(PVPK30). The Albendazole equivalent to 200mg, Mannitol and Microcrystalline Cellulose were mixed thoroughly in glass mortar using a pestle. Superdisintegrants were incorporated in the powder mixture according to each formulation in the tablets and finally Aspartame, and Magnesium stearate was added. The whole mixture was passed through Sieve No. 60 twice. Tablets were prepared using $12 \mathrm{~mm}$ round flat-faced punch of the rotary tablet machine [Jaguar (JMD4-8)]. Compression force was constant for all formulations are showed in Table 1.

\section{Precompression parameters}

\section{Angle of Repose}

Angle of repose was determined using fixed funnel method. The blend was poured through a funnel that can be raised vertically until a maximum cone height (h) was obtained. Radius of the heap (r) was measured and angle of repose was calculated using formula (Rockville et al., 2007).

$\theta=\tan ^{-1}\left(\frac{h}{r}\right)$

Where, $\theta$ is angle of repose, $h$ is height of pile and $r$ is the radius of the base pile.

\section{Bulk Density}

Apparent bulk density ( $L B D$ ) was determined by pouring blend into a graduated cylinder. The bulk volume $(V o)$ and weight of powder $(M)$ was determined. The bulk density was calculated using the formula (Rockville et al., 2007; Liberman et al., 1990). $L B D=\frac{\text { weight of the powder }(M)}{\text { volume of the packing }(V o)}$

\section{Tapped Density}

The measuring cylinder containing known mass of blend was tapped for a fixed time. The minimum volume (Vt) occupied in the cylinder and weight of powder blend (M) as measured. The tapped density (TBD) was calculated using the formula (Rockville et al., 2007; Mukesh et al., 2009).

$$
T B D=\frac{\text { weight of the powder }(M)}{\text { tapped volume of the packing }(V t)}
$$

\section{Carr's Compressibility Index}

The simplex way of measurement of the free flow of powder is compressibility, an indication of the ease with which a material can be induced to flow is given by compressibility index of the granules was

Table 2: Physical properties of powder blend.

\begin{tabular}{cccccc}
\hline Formulations & $\begin{array}{c}\left.\text { Angle of Repose } \mathbf{(}^{\circ}\right) \\
\pm \text { SD }\end{array}$ & $\begin{array}{c}\text { Bulk Density } \\
(\mathbf{g} / \mathbf{m l}) \pm \text { SD }\end{array}$ & $\begin{array}{c}\text { Tapped Densi- } \\
\text { ty }(\mathbf{g} / \mathbf{m}) \pm \text { SD }\end{array}$ & $\begin{array}{c}\text { Carr's Index } \\
(\%) \pm S D\end{array}$ & $\begin{array}{c}\text { Hausner's Ratio } \\
\pm \text { SD }\end{array}$ \\
\hline F1 & $27.97 \pm 0.34$ & $0.44 \pm 0.022$ & $0.66 \pm 0.022$ & $14.87 \pm 0.60$ & $1.52 \pm 0.008$ \\
F2 & $28.62 \pm 0.55$ & $0.41 \pm 0.018$ & $0.61 \pm 0.020$ & $13.72 \pm 0.27$ & $1.51 \pm 0.003$ \\
F3 & $27.65 \pm 0.39$ & $0.42 \pm 0.024$ & $0.70 \pm 0.024$ & $10.71 \pm 0.71$ & $1.13 \pm 0.009$ \\
F4 & $26.32 \pm 0.78$ & $0.38 \pm 0.037$ & $0.67 \pm 0.051$ & $15.31 \pm 0.99$ & $1.18 \pm 0.014$ \\
F5 & $25.71 \pm 0.59$ & $0.43 \pm 0.025$ & $0.72 \pm 0.036$ & $13.81 \pm 0.77$ & $1.58 \pm 0.011$ \\
F6 & $26.93 \pm 0.46$ & $0.41 \pm 0.024$ & $0.69 \pm 0.032$ & $12.96 \pm 0.49$ & $1.54 \pm 0.009$ \\
F7 & $27.65 \pm 0.43$ & $0.38 \pm 0.029$ & $0.62 \pm 0.036$ & $10.43 \pm 0.23$ & $1.51 \pm 0.006$ \\
F8 & $26.99 \pm 0.35$ & $0.44 \pm 0.019$ & $0.66 \pm 0.029$ & $14.60 \pm 0.81$ & $1.44 \pm 0.011$ \\
F9 & $28.62 \pm 0.38$ & $0.42 \pm 0.025$ & $0.61 \pm 0.051$ & $14.21 \pm 0.81$ & $1.55 \pm 0.011$ \\
F10 & $24.68 \pm 0.59$ & $0.47 \pm 0.025$ & $0.71 \pm 0.012$ & $13.30 \pm 0.81$ & $1.52 \pm 0.019$ \\
\hline
\end{tabular}


Table 3: Evaluation data of the prepared albendazole fast dissolving tablets.

\begin{tabular}{|c|c|c|c|c|c|c|c|c|}
\hline Formulations & $\begin{array}{l}\text { Thickness } \\
(\mathrm{mm}) \pm \mathrm{SD}\end{array}$ & $\begin{array}{c}\text { Hardness } \\
\left(\mathrm{kg} / \mathrm{cm}^{2}\right) \pm \mathrm{SD}\end{array}$ & $\begin{array}{l}\text { Weight } \\
\text { Variation } \\
(\mathrm{mg}) \pm \mathrm{SD}\end{array}$ & $\begin{array}{c}\% \text { Friability } \\
\pm \text { SD }\end{array}$ & $\begin{array}{c}\text { Disintegration } \\
\text { time (Sec) } \\
\text { Mean } \pm \text { SD }\end{array}$ & $\begin{array}{c}\text { Wetting time } \\
(\mathrm{Sec}) \\
\text { Mean } \pm \text { SD }\end{array}$ & $\begin{array}{c}\text { Water absorp- } \\
\text { tion ratio } \\
\text { Mean } \pm \text { SD }\end{array}$ & $\begin{array}{c}\text { Content } \\
\text { uniformity } \\
\text { Mean(\%) } \pm S D\end{array}$ \\
\hline F1 & $4.71 \pm 0.040$ & $33 \pm 0.12$ & $301.54 \pm 0.33$ & $0.52 \pm 0.18$ & $48.16 \pm 0.61$ & $40.22 \pm 0.25$ & $91.68 \pm 0.56$ & $99.27 \pm 0.63$ \\
\hline $\mathrm{F} 2$ & $4.55 \pm 0.039$ & $3.41 \pm 0.31$ & $300.65 \pm 0.32$ & $0.60 \pm 0.14$ & & $38.90 \pm 0.11$ & & .55 \\
\hline F3 & $4.56 \pm 0.055$ & $3.42 \pm 0.25$ & $301.48 \pm 0.64$ & $0.52 \pm 0.19$ & $40.51 \pm 0.23$ & $34.45 \pm 0.20$ & $109.34 \pm 0.81$ & $99.81 \pm 0.35$ \\
\hline F4 & $4.87 \pm 0.045$ & $3.36 \pm 0.13$ & $302.41 \pm 0.23$ & $0.58 \pm 0.11$ & $54.20 \pm 0.55$ & $36.15 \pm 0.24$ & $90.65 \pm 0.45$ & $98.85 \pm 0.20$ \\
\hline F5 & $5.01 \pm 0.049$ & $3.49 \pm 0.23$ & $300.60 \pm 0.21$ & $0.59 \pm 0.16$ & $57.86 \pm 0.82$ & $38.75 \pm 0.35$ & $88.36 \pm 0.78$ & $97.81 \pm 0.44$ \\
\hline F6 & $4.83 \pm 0.042$ & $3.42 \pm 0.37$ & $301.41 \pm 0.33$ & $0.49 \pm 0.14$ & $56.52 \pm 0.41$ & $36.65 \pm 0.53$ & $95.28 \pm 0.91$ & $98.92 \pm 0.87$ \\
\hline F7 & $4.87 \pm 0.052$ & $3.41 \pm 0.34$ & $300.30 \pm 0.12$ & $0.54 \pm 0.10$ & $48.52 \pm 0.84$ & $35.90 \pm 0.47$ & $90.91 \pm 0.78$ & $96.97 \pm 0.38$ \\
\hline F8 & $4.53 \pm 0.050$ & $3.50 \pm 0.06$ & $302.55 \pm 0.28$ & $0.61 \pm 0.20$ & $51.69 \pm 0.76$ & $34.98 \pm 0.58$ & $83.69 \pm 0.54$ & $98.64 \pm 0.29$ \\
\hline F9 & $4.44 \pm 0.044$ & $3.39 \pm 0.10$ & $301.50 \pm 0.36$ & $0.60 \pm 0.18$ & $55.60 \pm 0.63$ & $39.11 \pm 0.22$ & $90.65 \pm 0.89$ & $99.69 \pm 0.63$ \\
\hline F10 & $4.87 \pm 0.042$ & $3.37 \pm 0.10$ & $300.22 \pm 0.65$ & $0.67 \pm 0.24$ & $49.92 \pm 0.69$ & $37.50 \pm 0.45$ & $89.90 \pm 0.79$ & $98.78 \pm 0.84$ \\
\hline
\end{tabular}

${ }^{*}$ Results are presented as Mean \pm SD

determined by Carr's compressibility index (C) which is calculated by using the following formula (Rockville et al., 2007).

$C=\left[\left(T B D-\frac{L B D}{T B D}\right)\right] \times 100$

\section{Hausner Ratio}

Hausner ratio is an indirect index of ease of powder flow. It is calculated by the following formula (Rockville et al., 2007).

Hausner ratio $=\frac{\text { Tapped density }(T B D)}{\text { Bulk density }(L B D)}$

Where $T B D$ is tapped density and $L B D$ is bulk density. Lower hausner ratio $(<1.25)$ indicate better flow properties than higher ones $(>1.25)$.

\section{Post compression parameters}

All the batches of tablets were evaluated for various parameters like weight variation, friability, hardness, drug content, disintegration and dissolution and results reported in Table 3 .

\section{Uniformity of weight}

This test is performed to maintain the uniformity of weight of each tablet which should be in the prescribed range, this is done by sampling and weighing 20 tablets at random and average weight is calculated. Not more than two of the individual weights deviate from the average weight by more than the percentage show in the Table 3 and none deviate by more than twice the percentage The mean and standard deviation were determined (Thahera et al., 2012).

\section{Thickness}

The thickness and diameter of the tablets was determined using a Micrometer screw gauge. Five tablets from each type of formulation were used and average values were calculated. It is expressed in mm (Liberman et al., 1990).

\section{Hardness Test}

The hardness of the tablet was determined using Monsanto Hardness Tester (Rockville et al., 2007).

\section{Friability Test}

Six tablets from each batch were examined for friability using Roche Fribilator (Tropical Equipment Pvt. Ltd. Mumbai, India) and the equipment was run for $4 \mathrm{~min}$ at 25 revolutions per minute. The tablets were taken out, dedusted and reweighted and \% friability was calculated (Rockville et al., 2007).

Percent friability $=\frac{\text { Initial weight }- \text { Final weight }}{\text { Initial weight }} \times 100$

\section{Water Absorption Ratio}

A piece of tissue paper folded twice was kept in a Petri dish (internal diameter $5.5 \mathrm{~cm}$ ) containing $6 \mathrm{ml}$ of purified water. The tablet was placed on the tissue paper and allowed to wet completely. The wetted tablet was removed and reweighted. Water absorption ratio, $\mathrm{R}$ was determined according to the following equation (Bandari et al., 2008).

$R=\frac{\mathrm{wa}-\mathrm{wb}}{\mathrm{wawb}} \times 100$

Where $\mathrm{Wb}$ and $\mathrm{Wa}$ are the weight before and after water absorption, respectively.

\section{Wetting Time}

A piece of tissue paper $(12 \mathrm{~cm} \times 10.75 \mathrm{~cm})$ folded twice was placed in a small Petri dish (ID $=9 \mathrm{~cm}$ ) containing $6 \mathrm{ml} \mathrm{pH} 6.8$ phosphate buffer, A tablet was placed on the paper and the time taken for 


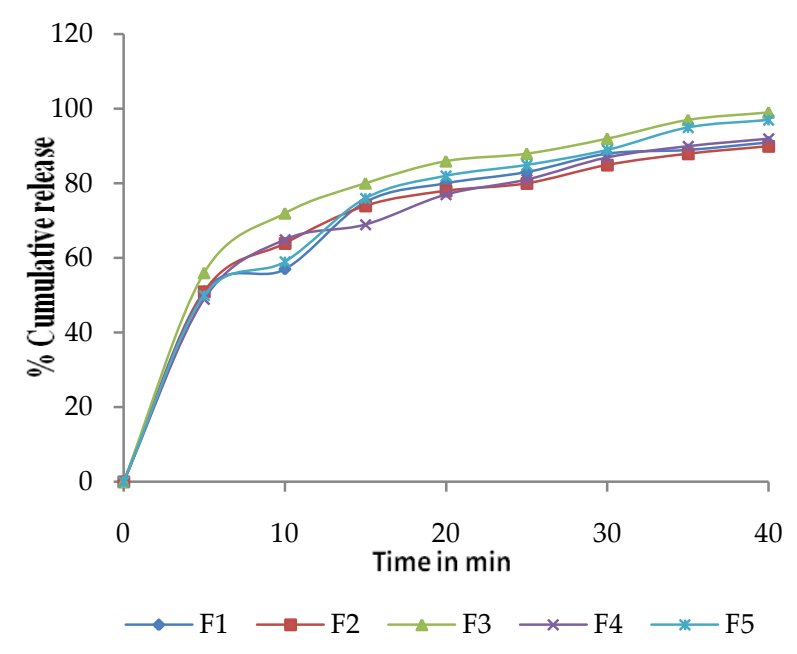

Figure 1: In vitro drug release of F1, F2, F3, F4, F5 tablet formulations.

complete wetting was noted. Three tablets from each formulation were randomly selected and the average wetting time was noted (Jain et al., 2012).

\section{Content Uniformity Test}

Twenty tablets of each type of formulation were weighed and crushed in mortar and powder equivalent to $200 \mathrm{mg}$ of Albendazole was weighed and dissolved in $100 \mathrm{ml}$ of $\mathrm{pH} 6.8$ phosphate buffer. From the stock solution $1 \mathrm{ml}$ sample was withdrawn and diluted to $10 \mathrm{ml}$ with $\mathrm{pH} 6.8$ phosphate buffer, The absorbance was measured at wavelength $291 \mathrm{~nm}$ using double beam UV-Visible spectrophotometer (IP, 2007).

Content uniformity was calculated using formula $\%$ Purity $=10 \mathrm{C} \frac{\text { Absorbance of unknown ( Au) }}{\text { Absorbance of Standard (As ) }}$

Where, C - Concentration

\section{In Vitro Disintegration Time}

Initially the disintegration time for fast dissolving tablets was measured using the conventional test for tablets as described in the Pharmacopoeia. Tablets were placed in the disintegration tubes and time required for complete disintegration without leaving any residues on the screen was recorded as disintegration time (EP, 1988).

\section{In Vitro Dissolution Testing}

Dissolution study was conducted for all the formulation using USP type-II apparatus (Electrolab, Mumbai, India.). The dissolution test was per-

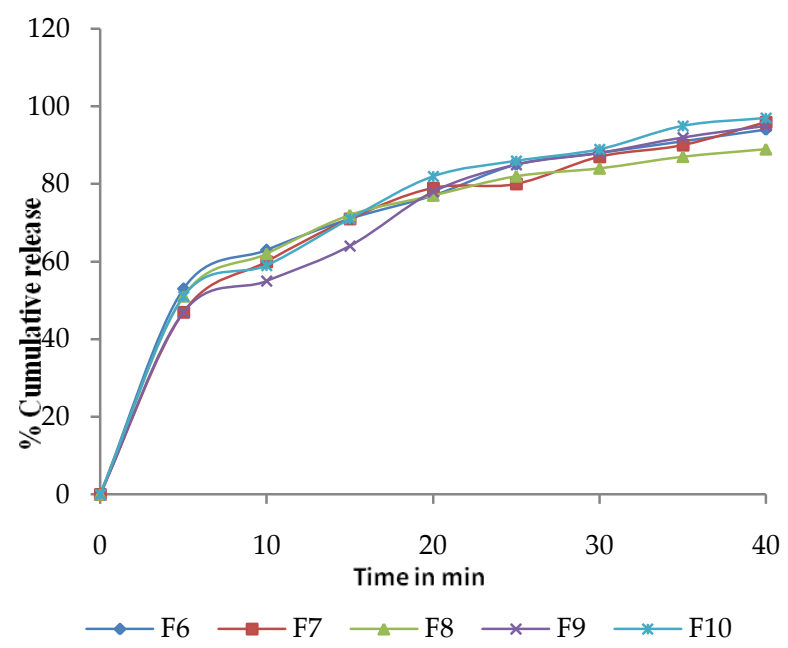

Figure 2: In vitro drug release of F6, F7, F8, F9, F10 tablet formulations.

formed using $900 \mathrm{ml}$ of phosphate buffer (PH 6.8) was taken as the dissolution medium at $50 \mathrm{rpm}$ and $37^{\circ} \mathrm{C} \pm 0.5^{\circ} \mathrm{C}$. Ten $\mathrm{ml}$ of aliquots were periodically withdrawn and the sample volume was replaced with an equal volume of fresh dissolution medium. The samples were analyzed spectrophotometrically at 291nm (Liberman et al., 1990).

\section{Characterization of albendazole tablet FT-IR studies}

Infrared spectrum was taken for the pure Albendazole. FT-IR studies was carried by $\mathrm{KBr}$ disk method using computer mediated Fourier transformed infrared spectroscopy (FTIR) (Shimadzu Model IRAFFINITY-1, Serial No. A21374600405 ).

\section{RESULTS AND DISCUSSION}

Albendazole fast dissolving tablets of were prepared by direct compression method was carried out by using superdisintegrants like Crospovidone, Croscarmellose sodium and Microcrystalline Cellulose in $5 \%, 4-5 \%$ and $15-20 \%$ concentration. Angle of repose: range from 24.68 to $28.62^{\circ}$ show good flow. Bulk density and tapped density: range from 0.38 to $0.47(\mathrm{~g} / \mathrm{ml})$, and 0.61 to $0.72(\mathrm{~g} / \mathrm{ml})$, respectively. Compressibility index and Hausner ratio range from 10.43 to 15.31 and 1.13 to 1.58 respectively. The results for recompressed parameters are showed in Table 2. 


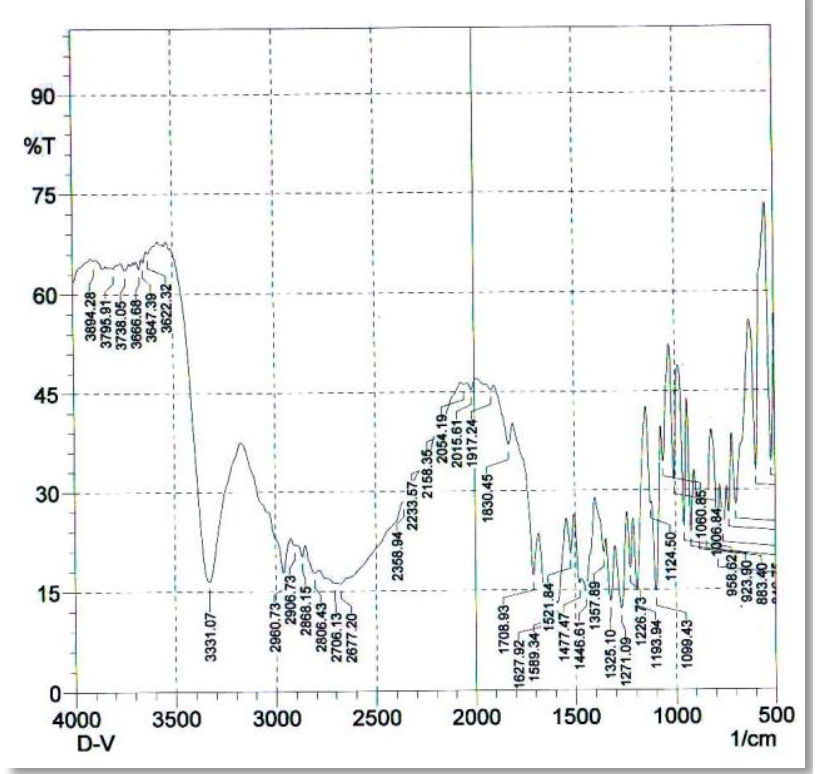

Figure 3: FTIR spectra of albendazole.

Weight variation test range from $300.22 \mathrm{mg}$ to $302.55 \mathrm{mg}$ as per IP specification. Friability: less than $0.67 \%$ the results indicate that the percentage losses were not more than $1.0 \%$. So the tablet complies as per IP specifications. Thickness: range from 4.44 to $5.01 \mathrm{~mm}$; the results indicate that the tablets are suitable for packing. Content uniformity: was found in between $96.97 \%$ to $99.81 \%$. Hardness of tablet was found to be between 3.33 to $3.50 \mathrm{~kg} / \mathrm{cm}^{2}$. The results indicate that the tablets are mechanically strong and are in limit. Disintegration time: in between 40.51 to 57.86 second the results indicate that disintegration time of tablets is within 1minute. Wetting time: in between 49.45 to 56.11 second and water absorption ratio was found to be 83.69 to 109.34 . The post compressed parameters are showed in Table 3. Dissolution Study in $6.8 \mathrm{pH}$ phosphate buffer: formulation of F1, F2, F3, F4, and F5 have a recorded drug release $91.87 \%, 90.80 \%, 99.07 \%, 92.85 \%$, and $97.48 \%$ at the end of $40 \mathrm{~min}$ the results was showed in Figure 1, formulation F6, F7, F8, F9, and F10 have a recorded drug release $94.88 \%, 96.43 \%, 89.80 \%$, $95.97 \%$, and $97.23 \%$ at the end of $40 \mathrm{~min}$ the result was showed in Figure No. 2. FTIR studies: The FTIR spectra of the pure drug were recorded in between 4000 to $400 \mathrm{~cm}^{-1}$. Characteristics peak and chemical group present in IR spectrum of Albendazole was showed in Figure 3, C-H Stretching of alkane at 2960 $\mathrm{cm}^{-1}$, -COO- Bending of Ketone at $1708 \mathrm{~cm}^{-1}, \mathrm{~N}-\mathrm{H}$ Stretching of amine at $3331 \mathrm{~cm}^{-1}$. Storage condition:
Tablets were stored at $45^{\circ} \mathrm{C} \pm 2{ }^{\circ} \mathrm{C} / 75 \%$ for a storage period of 0 days, 30 days, 60 days, and 90 days, Hardness was increases with time increases but in all cases, hardness was within the limit. Disintegration time: at various storage conditions increases but maximum 40 second which is less than 1 min (specification of IP). Dissolution studies shows there was no significant difference in dissolution data of formulations at initial and after specified storage period.

\section{CONCLUSION}

Fast dissolving tablets of Albendazole can be successfully prepared by direct compression techniques using selected superdisintegrants for the better patient compliance and effective therapy. The relative efficiency of these superdisintegrants to improve the disintegration and dissolution rate of tablets was found in order i.e. Crospovidone > Croscarmellose sodium.

\section{ACKNOWLEDGEMENT}

The authors are grateful to Brassica Parma Ltd., Boisar for providing gift sample of Albendazole and Curex Pharma, Jalgaon for providing Croscarmellose sodium, Crospovidone and Microcrystalline cellulose.

\section{REFERENCES}

Bandari, S., Mittapalli, R.K., Gannu, R., Rao, Y.M. (2008) Orodispersible tablets: An overview, Asian Journal of Pharmaceutics, Jan, Pp. 2-11. [DOI]

Bradoo, R., Shahani, S., Poojary, S., Deewan, B., Sudarshan, S. (2001) Fast Dissolving Drug Delivery Systems. JAMA India, 4(10): 27-31.

Cook, G.C. (1990) Use of benzimidazole chemotherapy in human helminthiases: Indications and efficacy. Parasitol. Today, 6: 133-136. [DOI]

European Pharmacopoeia. (1988). Directorate for the Quality of Medicines of the Council of Europe (EDQM), Vol. 2. (5th ed., Pp. 2104-2107).

Indian Pharmacopoeia. (2007) Government of India, Ministry of Health and Family Welfare, Ghaziabad, Vol. 2. (pp. 663665). New Delhi, The Indian Pharmacopoeia Commission Publisher.

Indurwade, N.H., Rajyaguru, T.H., Nakhat, P.D. (2002) Novel approach fast dissolving tablets. Indian Drugs, 39(8): 405409. 
Jain, N., Mandal, S., Banweer J. and Jain, S. (2012). Effect of superdisintegrants on formulation of taste masked fast disintegrating Ciprofloxacin tablets, International Current Pharmaceutical Journal, 1( 4): 62-67. [DOI]

Kuchekar, B.S., Badhan, A.C., Mahajan, H.S. (2003) Mouth Dissolv-ing Tablets: A Novel Drug Delivery System. Pharma Times, 35: 7-9.

Lachman, L., Lieberman, H.A., Kanig, J. L. (1990). Banker, G. S., Anderson, N.R. In: The Theory and Practice of Industrial Pharmacy (3rd ed., pp. 296- 302). Mumbai, Varghese Publishing House.

Mukesh, P., Ratnaparkhi., Mohanta, G.P., Upadhyay, L. (2009) Review on: Fast dissolving tablet. Journal of Pharmacy Research, 2(1): 5-12.

Rockville, M.D. (2007) United States of PharmacopeiaNational Formulary. USP 30 - NF 25, Vol 1, (PP. 634-645). The Unit States Pharmacopeial Convention.
Seager, H. (1998) Drug-delivery product and the zydis fast dissolving form. J. Pharm. Pharmacol, 50( 4): 375-382. [DOI]

Shu, T., Suzuki, H., Hironaka, K., Ito, K. (2002) Studies of rapidly disintegrating tablets in the oral cavity using cogrinding mixtures of mannitol with crospovidone. Chem. Pharm. Bull, 50: 193-198. [DOI]

Thahera, P.D., Latha, A.K., Shailaja, T., Nyamathulla, S., Uhumwangho, M.U. (2012). Formulation and evaluation of Norfloxacin gastro retentive drug delivery systems using natural polymers, International Current Pharmaceutical Journal, 1( 7): 155-164. [DOI]

Wen, H., New, R.R.C., Craig, P.S. (1993) Diagnosis and treatment of human Hydatidosis. Br. J. Clin. Pharm, 35: 565-574. [DOI] 